\title{
THE DYNAMICS OF GERMAN CARTELS AND PATENTS. II*
}

\author{
HEINRTCH KRONSTEIN† \\ DEVELOPMENT UNDER HITLER
}

$\mathrm{H}$ ITLER came to power in I933, a year when people of all nations lacked food, clothing, and houses. Millions of German workers and billions of German marks were unemployed as a result of a radical domestic policy of deflation, a destructive crisis in the international market, and a stupendous lack of ideas in world economy. Organizations of German employers and employees had frozen the standard of wages without regard for the effect the "freezing" was to have on the unemployed. These unhappy people were referred to unemployment "insurance." Other organizations of German merchants and industrialists controlled the prices of almost all products; the price structure was to be maintained even though it meant bankruptcy for any single member. These organizations did not care for the needs of the consumer or the political situation within the Reich. Cartels of international merchants added to the depressed condition. Disregarding developments in supply and demand these organizations had frozen prices for raw materials and had restricted production schedules. Since foreign investment funds were being recalled from Germany, no money was available for raw material needs. Germany was faced with an immediate crisis. ${ }^{\text {I }}$

When Hitler's experiment began, public opinion was crystallizing along two important lines. There was growing demand that the Government make more flexible the rigid price structures resulting from cartelization and unionization; and, that the Government make Germany increasingly independent of the cartels in control of foreign raw materials, primarily rubber, tin, zinc, and mercury. The revolutionary National Socialist movement could not possibly have been in a happier situation than to find

* This is the second and final instalment of The Dynamics of German Cartels and Patents. Part I appeared in 9 Univ. Chi. L. Rev. 643 (1942).

† Adviser in foreign law and property, Department of Justice, Anti-Trust Division; Professor of Comparative Law, Georgetown University Law School; formerly practicing attorney in Mannheim, Germany, specializing in cartel and monopoly law. The views expressed are the views of the writer and not those of the Department of Justice.

- For a discussion of the general background and an admirable analysis see Neumann, Behemoth (x942). 
the country unified in regard to certain needs. It does not matter if these measures were part of the early program of the National Socialists or not. They helped to give form and meaning to a plan of action formulated by this group which suddenly found itself in control. The fact that the economic situation of most of the German people was so desperate added to the pleasant circumstances in which the revolutionaries found themselves. The average German felt that under no circumstances could conditions become worse.

Excluding the complete nationalization of industry, there were two possibilities open to Hitler. Those industrialists who were forced to shut down their plants during the depression could be refinanced from the idle funds of the nation. At the same time the cartels could be temporarily tolerated in order to maintain a relatively high price level. This transitory period would enable the firms which were in a technically weak position to improve and strengthen their organizations so that later they would be able to compete in a fight of free but state-controlled competition. The alternative was to forget those entrepreneurs who got into difficulties during the depression and concentrate on increasing the efficiency of the survivors within the existing cartel structure. Behind the scenes, gigantic struggles went on between opposing groups. In the first Hitler-Hugenberg Government the names Schmidt, Keppler, and Wagner became symbols of this fight only to sink into obscurity later.

Those who supported the refinancing scheme argued that the early history of the National Socialist party was in accord with their view. ${ }^{2}$ On the other hand, the friends of the program to strengthen the existing cartel organizations had effective arguments in their favor. They claimed that the early stand of the National Socialist party was merely a reaction against the super-organizations which had sprung up in World War I. They had

${ }^{2}$ Feder, Hitler's Official Program and Its Fundamental Ideas $\S r_{3}$ (I938) explains $\S I_{3}$ of the program of the National Socialist party drafted February 23 , I920. "I3. Big business (syndicates, trusts) will be nationalized. This demand is consistent without general war upon the capitalist idea. The first aim of syndicates and trusts in any particular branch of production is to unite with other similar businesses for the purpose of dictating prices. They are governed by no desire to distribute good wares at a cheap price. Such 'rings' are especially attracted by new businesses which are doing well. New firms . . . . are bought up and put out of the way.... . Supply is regulated by pooling, by which means they are able to regulate prices in accordance with an apparently genuine 'supply and demand.' This is what interests the shareholders, who have no desire to see prices kept low by competition. New ideas and inventions are viewed with a hostile eye, and preferably suppressed if their adoption would endanger the paying capacity of older plants. Such businesses, run as huge trusts from a central office are clearly 'ripe for socialization,' i.e., they have ceased to fulfill any of the services to the community which individual competition performs. They are by hypothesis stereotyped, and only serve the greed of capitalism." 
made the farmer, worker, and housewife cogs in the machine of economic warfare. Therefore this early National Socialist party plank was only an expression of opposition against the extreme socialist trend of the era. In the post-war period, particularly between I925 and I933, the anti-capitalistic feeling was growing. This phenomenon occurred not only outside of the National Socialist party but within the party itself. The party ended its first, South German, period with the Munich defeat. The second, North German, period opened with an alliance with powerful industrial groups that insisted upon total organization. From the time of this alliance forward there was a growing conviction that national German existence could be revived only under a structure of a strong economic organization guided by active governmental participation. ${ }^{3}$

A further argument put forth by the group supporting the second alternative, increasing the efficiency of the industries which survived the depression, was that the existing Italian Fascist ideas were in accord with such a program. However, the first Italian minister for the corporate structure for Italy expressed the real Italian view when he stated that the aim of the statute relating to compulsory cartels was to "bring the direction of the cartels in line with the corporate society which supervises and mitigates difficulties and overcomes them. If the cartels are not supervised or not regulated by the interference of the government they are necessarily opposed to a corporate society. We will not permit the cartels to call themselves part of a corporate society as long as they practically are what they were in a liberal interpretation of the state." 4

The principal argument of the proponents of the program to strengthen the existing cartel system was inherent in the German situation and in the trend of the revolution itself. The organizational development between I920 and 1933 had progressed to a point where it would have been almost an impossibility to destroy the structure. Even revolutions are bound to be affected by existing social and economic structures. A total economic organization provides an excellent background to a dictatorship and its future actions which in turn guarantee its existence. A self-regulating economy is hostile to any dictatorship or revolutionary movement. The decision, then, was in favor of the cartels as far as the form of organization was concerned. The spirit and the direction of the institutions, however,

3 The monthly publication, Tat, promulgated this doctrine. Its influence in the strengthening of these ideas cannot be overestimated.

4 Speech in House of Representatives, April 20, I932, reported in Note informative sul progetto di Legge italiano sui consorzi economici, Kartell Rundschau 4 5 (I932). (Secondary sources must be used since the Italian records of the House of Representatives are not a vailable to the writer.) 
was radically changed. It was a decision in favor of a cartelized economy as a tool of force, a decision in favor of technical efficiency and against social efficiency.

This decision was made clear by the following restrictions of the Government: a) The plants which were shut down because of the depression were to a large extent prohibited from reopening. b) New enterprises throughout industry were not allowed. c) Existing producers could not enlarge their capacity unless licensed. d) The increase of cartel prices was prohibited unless licensed. 5 The official reason for these rules naturally attempted to make them appear quite harmless. It was said that "these provisions were substantially based on economic necessity to prevent mistaken investment of capital if the existing plants are sufficient to cover the needs of the nation, just now when our economy needs such capital for its reconstruction and security of employment. The statute does not aim to prepare for an economy planned by the state or to change the present basic economic constitution which encourages initiative and responsibility of entrepreneurs. The power granted in the statute shall be exercised only with great reluctance and solely in those cases when private industry itself cannot find its way out of existing difficulties." 6

These measures solved a number of difficulties for the cartel managers. Any new plants or reopened enterprises would naturally disturb the internal situation of the cartel organization. The fight between the cartel managers and the members over production quotas was the most vicious controversy put to rest. Furthermore, the price provision was a disadvantage to the technically weaker members because they lost the protection of a saving cartel price. ${ }^{7}$ This price protection given to the technically weakest member runs all through discussions of the cartel problem. As late as September, I94I, a German price commissioner demanded a cartel system in which prices should be based on the costs of the "good" enterprise and not average costs. ${ }^{8}$ The Hitler Government inaugurated an antideflationary policy. The effect was a rise in prices in which cartel mem-

5 The first three restrictions are part of the statute relating to compulsory cartels: "The R.W.M. may provide by decree that in the scope of a certain part of the national economy the establishment of new enterprises or the enlargement of the plants and of the capacity of existing enterprises shall be prohibited for a certain period or require a license whenever a special need of such parts of the national economy makes such ruling advisable in the interests of the common welfare. . . . " Statute of July 15 , I933, I Reichsgesetzblatt 488-89. The last restriction was expressed in the decree of December II, I934, I Reichsgesetzblatt I248.

${ }^{6}$ As reported in Kartell Rundschau 5 I7 (1935).

7 The number of decrees entered may indicate the scope of governmental activity: I935, I2; 1936, 6; 1937, $5 ; 1938,33 ; 1939,74$.

8 Plea of the Chief of the Iron Division in the Office of the German Price Commissioner. Kartell Rundschau 335 (I94r). 
bers did not participate. Cartel members who did not have very strong research facilities could not produce cheaper and had to bear the burden of the whole policy. These members could not withdraw because under the statute relating to compulsory cartels even independent producers could be joined to an existing cartel by decree of the Government. ${ }^{\text {The man- }}$

9 A quotation from one decree establishing a compulsory cartel gives the best idea to what extent such a compulsory member of a cartel is a prisoner of the cartel managers:

"In accordance with the statute relating to compulsory cartels of July I5, x933, I Reichsgesetzblatt 488 , I decree the following:

SECrion 1 . The persons or enterprises who prepare natural and synthetic gems or diamonds for commercial use or license their preparation by other persons or enterprises are hereby combined into an association of gem processors. All persons or enterprises who establish such a plant covered by the first sentence, after the issuance of this decree will be joined to the association.

SEc. 2. The association of gem processors will have the attached charter and by-laws. The charter and by-laws are part of this decree and can only be changed by my consent. The association is to be considered a juridical person. The members cannot leave the association. The membership comes to an end when the member ceases to be active in an enterprise covered by Sec. I. For myself I reserve the right to permit a member to leave the association for special reasons.

SEc. 3. A person becoming a member based on Sec. I has to inform the association of his address and the products manufactured in his plant within a week after the issuance of this decree or in the case of Sec. I, sentence 2, within a week after he establishes his plant.

SEc. 4. The first meeting of the members shall take place within one month after the issuance of this decree.

SEC. 5. The first meeting of the members can elect the representatives of the association. The president of the National Socialist "Fachgruppe" of the gem processors shall take care of the administration of the association.

SEc. 6. In case of any difference of opinion if a person is a member in accordance with Sec. $I$ or not, I decide the question. So far as all other questions are concerned, the ordinary court proceedings and the jurisdiction of the cartel court shall remain in force.

SEc. 7. The members of the association are responsible for all expenses which should become necessary in connection with any measures of supervision of the association. I will establish the amount of these costs. If such costs should not be reimbursed they will be considered as taxes.

SEc. 8. Whoever violates Sec. 3 of this decree knowingly or intentionally or who violates any decree issued in amendment or for the purpose of the execution of this decree, or who violates any order issued on the basis of my authority as supervisor shall be punished by the cartel court with a fine, if he should make such an application to the cartel court. The amount of the fine is unlimited.

SEC. 9. This decree is in force from the day of its publication. I am entitled to revoke this decree at any time. (July 23,1934, R.A. No. 172 of July 26. )

Charter and By-Laws.

SEC. I. Task of the Association: The association is to regulate competition between the processors dealing with natural and synthetic gems by fixing prices and conditions of delivery and payment. The association may make any agreements with associations of other business organizations and other parts of the gem commerce.

SEC. 2. Name of the association.

SEC. 3. The association is represented by the chairman or the acting chairman in the committee and the meeting of the members.

SEC. 4. The chairman and the active chairman shall be elected by the meeting of the members for two business years. After the end of the period for which the chairman and acting 
agers were aware of the compulsion inherent in this device, hence outsiders and the less satisfied members were threatened with a compulsory decree. In addition, the managers mustered as much political pressure as

chairman are elected, they shall remain in office until new successors have been elected. The meeting of the members may revoke the election by three-quarters of the votes of the members, if a justification for the revocation exists.

SEc. 5. The chairman represents the association in court and outside of court. He has the position of a statutory agent of the association. He is responsible for the current administration, especially the invitation of the members to a membership meeting, the execution of the resolutions of the committee and the membership meeting, the collection of the fees of the members, the collection of claims of the association against the members based on violation of the by-laws, and the resolutions of the committee and the membership meeting.

SEc. 6 . The committee shall consist of the chairman and four members. The members and their representatives shall be selected by a membership meeting, for two years. After this period they shall remain in office until new members are elected.

SEc. 7. The committee shall establish the prices, conditions of delivery and payment in accordance with general rules to be established by the membership meeting. The committee decides these questions by a majority vote. A member shall not be entitled to vote if the resolution has to do with the settlement or the beginning of a law suit between him and the association. The resolutions of the committee shall be reported in written form.

SEc. 8. The membership meeting shall be called in the first months of the business year if a quarter of the members should require such meeting, or if the R.W.M. should do so or if the interests of the association so require. Members shall be notified of meetings by registered mail with one week's notice mentioning the schedule. In especially important cases a membership meeting can be called by telegram with three days notice. Members who are domiciled at the place of the meeting can be called informally against receipt.

SEc. 9. The membership meeting regulates the matters of the association within the scope of the charter. The membership meeting may change the by-laws with the consent of the R.W. M. The membership meeting may change the resolution of the committee. The membership meeting selects the chairman and the members of the committee. The membership meeting decides the amount of the fees, the discharge of the chairman and the bank or the agency to which payments are to be paid as fines.

SEC. Io. The chairman of the association is the chairman of the membership meeting. Every member has one vote. A member is not entitled to vote if the resolution has to do with the beginning or the settlement of litigation between himself and the association. The membership meeting shall have a quorum of two-thirds of the members. If no quorum exists a new membership meeting shall be called which shall decide without a quorum. The resolutions of the membership meetings require a simple majority of the members who appear in the meeting. In case of change of the by-laws, however, a three-quarters majority is necessary. The change of a resolution of the committee can only be decided on by a majority of the members. If in case of election no person receives more than $5 \circ$ per cent of the votes of the members who appeared in the meeting, a second vote is necessary.

SEC. Ir. The members are obligated to the association as well as to each other, to obey the rules relating to the competition established by the committee in the membership meeting or by order of the R.W.M. The committee supervises the execution of such resolutions and rules. The committee may entrust the investigation of certain violations to proper persons. The members are obliged to give all information to the committee or its representatives to the extent such information is necessary to make possible a proper supervision and to permit the examination of the books. A member against whom any supervisory measure has been taken may demand that a public accountant shall be entrusted with the execution of the measure." 
influence and friendship with the leading party members allowed them. The cartel court, too, helped to imprison the independent as well as the dissatisfied member. It specifically held that any member who had joined $a$ cartel voluntarily or by governmental decree could not sever his relationship. ${ }^{\mathbf{x}}$ Even more drastic was the holding of the Reichsgericht that members who were bound by governmental decree had no recourse open to them in the courts since the decree was conclusively binding..$^{\text {Ix }}$ The number of entrepreneurs joined to cartels as well as the number of cartels skyrocketed. ${ }^{x z}$

After the Government had made it possible for the cartel managers to ignore the weaker members of the cartels by reason of the above described legislation, the question of who was to supervise the cartels remained.13 Those who criticized the steps the National Socialist party had taken were not satisfied with the general statements that these cartels, reorganized in the spirit of the National Socialist philosophy, serve only one aim, the common welfare, while the cartels of the pre-Hitler era served their own profit.

In seeking a solution to the problem of supervising the cartels the Italian method was discussed. In Italy the supervision was entrusted to the so-called "corporations". ${ }^{14}$ These corporations were instruments of the corporate society. They were in reality associations of employers and employees which were established by the state to assist in state administration. As a supporter of this Italian structure said, the aim of the corporation is to regulate the relationship between capital and labor, to interfere in litigation about collective agreements, to give opinions about economic problems, and to issue rules relating to production, sale, and prices. The Italian method of cartel supervision was absolutely in line with the principal ideas of the Ständestaat..$^{15}$

Those who did not favor the Italian scheme argued that supervision of the cartels by groups with completely divergent views merely slowed up

so Kammergericht of March 28, 1935, Kartell Rundschau 398 (1935).

xx Reichsgericht of November 2, 1937, Juristische Wochenschrift 3255 (1937).

: See note 7 supra.

${ }^{33}$ Besides freeing the cartels from their obligations to the weaker members, legislation freeing the cartels from the threat of union opposition had been passed. Gesetz zur Ordnung der Nationalen Arbeit, Reichsgesetzblatt 45 (1934).

"Statute of June I2, 1932, reported in Kartell Rundschau 412 (1932), gave the "corporations" the following supervising functions over cartels: a) general control of the cartel files; b) general advisory capacity for informing the Government on all problems relating to cartels; c) general policing power over the cartel which is made effective by reports to the Government when any cartel policy appears to be opposed to the aims of the Government.

rs Spann, Tote und Lebendige Wissenshaft (3d ed. I929). 
the efficiency cartels were designed to promote. It was pointed out that the "Stände" themselves, if they had their way in setting up a structure similar to the Italian one, might thereby set up a new version of the economic system and then settle down in it. The Frankfurter Zeitung criticized the Italian corporations because of the slow and unimaginative reaction they displayed in connection with the sanctions the League of $\mathrm{Na}$ tions had imposed on Italy. ${ }^{16}$ The press in general favored a super-corporation, identical with the state for a social and economic situation such as existed in Italy.

While the Ständestaat structure of the state was part of the early program of the National Socialist party, the party alleged only a temporary withdrawal from this objective for a new program-the so-called organic structure of the society. Like all political parties the National Socialists made the shift in aims appear to be no shift at all. This apparently was the solution promised all along. In I934 the statute purporting to establish the organic structure of the German economy was passed. ${ }^{17}$ Certain Wirtschaftsgruppen with semi-official character and compulsory membership were created. ${ }^{8}$ The party insisted that these groups-the Reichsgruppe, Wirtschaftsgruppen, Fachgruppe, Fachuntergruppe-were quite distinct from the cartels. While the main purpose of cartels is to regulate markets by price-fixing, market allocation, and production schedules, the various "Gruppen" were to refrain from such activity. They were, rather, to keep the people in a particular trade "clean" and well-educated. They were to maintain a constant surveillance so that only those with the necessary experience and education entered a trade and, once in the trade, the worker was not to exceed the bounds of his experience and education. It is obvious that these groups covered a broader field than the cartels: The managers of the groups are supposed to be experts in their fields, not individuals interested in business because of the profits involved as the cartel managers were. Furthermore, the groups are supervised by Hitler while the cartel managers are supervised and managed by private cartel members who act for the private interests. ${ }^{x}$

${ }^{16}$ Frankfurter Zeitung (Jan. I, 1936).

${ }_{17}$ Statute of February 27, I934, Reichsgesetzblatt I85 (1934). The statute should be studied in connection with the first decree issued in execution of the statute, Decree of November 27 , I934, ibid., at Ir94, and the circular decree of the Reichswirtschaftsminister, July 7, I936, Reichsanzeiger I $_{57}$ n. 2 (I936).

${ }^{8} \mathrm{~A}$ study of the structure of these groups is of vast importance for understanding the German economy. See Gliederung der Reichsgruppe Industrie (3d ed. 194I) for a helpful report.

19 It must be pointed out that the cartel managers are not selected by the private interests exclusively; the appointment is by grace of the Fuehrer. See Mönkmeier, Nationale Wirtschaft 354 (I937). 
When the "organic structure" program was launched the cartels were considered merely a necessary stop-gap in the establishment of the new economy. In time each member of society would act just as the common welfare dictated - the groups, replacing the cartels would be the exclusive future agencies. ${ }^{20}$ The Secretary of Commerce (R.W.M.) was so impressed with the distinctions between the groups and the cartels that supervision of the cartels by the groups followed as a natural course. ${ }^{2 x}$ This was heralded as a step in the direction of a self-administering economy. At this point, however, the fulfilment of a prophecy took place. As early as I933 a noted economist said, "Since the idea of a corporate state is now an actuality, we may expect that economic groups interested in cartelization and monopoly will use the corporate idea for their own private interests. Experience has taught us that interested groups use political ideologies as soon as they become influential. The developments after the last war are evidence that cartels made their demands of government under the various guises of labor or freedom of competition, planned economy or economic democracy, sometimes under the slogan of freedom of coalition. Now these cartels will attempt to accomplish what they could not before under the name of market regulation. If it should come to pass that the cartel managers take over market regulation and also get power over political regulation, nothing in the world will be able to prevent their economic interest from gaining the upper hand. They will twist the idea of the cooperative state, falsify its institutions, sooner or later destroy this state. ${ }^{\prime 22}$

The groups supervised the cartels with the aid of the following devices:23 a) A register for all cartel members was established. b) All resolutions of the cartels must be filed with the Wirtschaftsgruppe. c) The Wirtschaftsgruppe acquired the right to attend all meetings of the cartels. d) All proceedings were to be reported to the R.W.M. The groups have been concerned with about $I, 700$ industrial cartels which have been registered under the appropriate provision. About one-half of these registered cartels were created solely for dealing with problems of delivery and payment of merchandise. The material filed under the registration provision is used

${ }^{20}$ It was said that only the future would reveal whether or not the cartels could be abandoned. This would be the test of the National Socialist program of "organic structure." Tschierschky, Kartellfrage als Gegenwartsproblem, Kartell Rundschau 322-23 (1935).

${ }^{2 x}$ Decree of November I2, I936, Kartell Rundschau 749 (1936), ordering cooperation between the organization of commerce and those organizations dealing with market regulations.

23 For special reasons the name of the author and the source are omitted.

23 Decree of November 12, I936, Kartell Rundschau 749 (1936). The R.W.M. decreed that "an additional means of publicity was created by $\S 128, \Upsilon_{2}(9)$ of the corporation statute of January 30, 1937. Corporations must henceforth mention their membership in any association dealing with the regulation of markets or prices."- 
to a large extent in strengthening the position of the cartel. For example, the reports indicate where greater uniformity in conditions of delivery and payment can be obtained. ${ }^{24}$ Reports indicating the exercise of the right of supervision, however, are rather scarce.

It was obvious from the very establishment of the groups that the distinctions between them and the cartels did not justify the division. Nothing in the new structure showed why one of these organizations should be able to supervise the other in the interest of the common welfare. The membership in the groups was limited to industrialists of the trade that was to be regulated. The only difference was that a member of a group might be chosen from a wider field of choices than a member of a cartel. Although the National Socialists protest that it is not so, exceptions are permitted that enable cartel managers to act as group managers at the same time-in effect, supervisors who supervise themselves. Another case with the same deleterious effect arose when the cartel manager and the group manager were members of the same enterprise. Finally, the distinctions became so blurred that the groups were permitted to regulate the markets themselves. ${ }^{25}$ There were other cases where the cartels flatly took the position that they represented the entire field that the group intended to cover. This included all the group tasks, even the supervision of admission to the industry.

Because the description of the state and its cartel structure thus far given appears to present a favorable situation for those operating behind the cartels one might justifiably ask the question, why did not the dangers which confronted the Weimar republic reappear. The answer is that the supervision of these organizations did not remain the foremost politi-

24 First report of Reichsgruppe der Industrie, Kartell Rundschau 372 (I937).

${ }_{25}$ This development is shown by the following: "To avoid any doubt I give you the following information: Transformation of associations into groups constituting the organization of commerce as provided by $\S 6$ of the first decree authorizing the organic structure of the German economy must be accomplished even if the association is doing some work in market regulation while it is predominantly engaged in a general economic policy. The chief of the group may require the assaciation to transfer the market regulation activities to outsiders, or he may find other ways and means, provided he has my permission, which will have the same effect as required by $\S 6$ of the Decree of November 27 , I934.

"Associations engaged exclusively in market and price regulations shall refrain from other activities. The groups, however, may observe the problems of market regulation and act as advisers in such problems. These groups may request the association dealing in market regulations .... to report all market regulation agreements which exist together with all the duties of the members arising thereunder. I rely upon a faithful cooperation between the groups and the cartels engaged in this market regulation. In case of any differences or complaints I shall ask for a report." Statement of the R.W.M. to the Reichsgruppe Trade, June 4, I935, reported in Kartell Rundschau 554 (1935). (Italics added.) 
cal issue. The National Socialist party and its executive committee, the Government, preoccupied the nation with but one aim-rearmament. It is apparent today to what extent the devotion of the entire economy to the rearmament effort changed the economic situation of the German nation. The cartels and groups became a part of the machinery of a war economy without losing their identity just as American industry is not losing its identity by the exclusive production of war materials.

The confines of this article prohibit an exhaustive treatment of all the facets of the various cartel problems; the trends of latest developments can perhaps best be shown by investigating a few specific areas of conflict.

The power of groups and cartels to decide who can do business in indusiry and commerce.-Both before and after 1933 the prime concern of cartels has been to find ways of excluding producers from the field the cartel seeks to protect, thus reducing the number of possible competitors. These organizations particularly sought to impose minimum requirements for admission to participate in an industry or trade. The conditions the cartels would like to see in force would practically preclude one from entering any kind of business activity. The cartel court held ${ }^{26}$ that such measures would abolish the freedom of commerce guaranteed by the German Constitution $^{27}$ and the appropriate commerce statute. ${ }^{28}$ Likewise under Hitler this same court refused to allow the cartels to settle questions regarding the needs of their respective industries as a matter of their own right. ${ }^{29}$ This court, however, did permit them to establish certain minimum requirements forbidden before. ${ }^{30}$ Their control over any newcomer in the business was thereby established. It is obvious that this power would prove a dangerous weapon in the hands of interested people. ${ }^{3 \mathrm{x}}$

The cartels attempted to educate the German people to consider it unethical for one person to engage in several phases of the economic process either as manufacturer and dealer, or as a manufacturer of several unre-

\footnotetext{
${ }^{26}{ }_{3}$ Entscheidungen und Gutachten des Kartellgerichts, No. 75 (K-485 \& K-486-25, April 22, I926).

${ }^{27}$ Weimar Const. art. 15I.

${ }^{28}$ Statute of July 26 , I900, Reichsgesetzblatt 87 r (rgo).

29 Decision of the Kartellgericht, reported in Kartell Rundschau 574 (I935).

$3^{30}$ Decision of the Kartellgericht, reported in Kartell Rundschau 409 (1938).

${ }^{3 x}$ Perhaps this is what Hitler referred to as the "sleeping influence" of the planned economy in his speech of May 21, 1935, Frankfurter Zeitung, May 22, I935. A decree of the R.W.M. typifies the spirit of these minimum requirements. In this decree governmental agencies which have to deal with applications for doing business in the wholesale trade were to consider whether the applicant is reliable, experienced, and financially responsible. 4 Mitteilungsblatt des R.W.M. 46 (I940).
} 
lated products, or as a dealer in several unrelated products. ${ }^{32}$ Furthermore, these cartels were anxious to promote the feeling that it was unethical for a man to engage in a business unless it was understood that this was his only business. ${ }^{33}$ It was also unethical to start in business without a proper office and sufficient equipment and stock. ${ }^{34}$ Under Hitler this division of business activity and the enforcement of minimum requirements for entering a business were used as a part of the agreements entered into by the cartels and groups engaged in trade enterprises and those who classified themselves as industrialists. A typical example of this kind of general agreement is the one entered into by the Central Organization of Coal Traders and the Association of German Mining Syndicates on July 27, I934. The agreement deals with three problems: a) rules of admission to the coal trade; $b$ ) a division into strict categories of the retail and wholesale coal trade; and c) price protection for the retail trade. The mining syndicates agreed to supply only merchants recognized by the Central Organization of Coal Traders, which was alleged to mean those traders who possessed the ability of an expert coal trader, were completely reliable, and had established a coal business absolutely necessary to the community in which they proposed to do business.

The fact that two organizations can determine who can and who cannot do business in such a common commodity as coal is indicative of their power. Furthermore, the fact that the two organizations blend into something called the Wirtschaftsgruppen which is supposed to refrain from market regulations, only adds to the confusion. As a result, gigantic economic power rests in the hands of a few. A most important element, however, is that both organizations require that admission to the business be accompanied by membership in all the relevant cartel organizations. Traders would only be supplied as long as they remained members. The result of this private compulsion was an increase from 8,000 in I 933 to 54,000 in I937 in the number of cartel members in the coal business. This means that all the coal traders of Germany are members at this time.

The power of cartels and groups over the exclusive use of products.-Once

${ }^{32}$ The statements of the National Socialist economists alleged that the Government was to have the last word on these matters of economic structure. The Kartellgericht, nevertheless, held otherwise. They said, "The cartels must support the aim of the national leadership and describe as exact as possible the several phases in the structure of the economy. They must prevent any transgression of any person engaged in any of the described phases." Decision of Kartellgericht, reported in Kartell Rundschau 83 (1936).

${ }^{33}$ Recognized in a decision of the Kartellgericht, reported in Kartell Rundschau 555 (1937).

$34 \mathrm{~A}$ line of decisions dealing with the radio business emphasizes this qualification. Decision of the Kartellgericht, reported in Kartell Rundshau 409 (1938). 
an entrepreneur is brought into the cartel his production is subject to its command. The power to control the output of a producer is used for a variety of purposes. For example, the cartel may enter into an agreement with another cartel to restrict sales so that a potential competitor will not even be able to get started. The agreement entered into by the Association of Printers and the Association of Manufacturers of Printing Equipment limiting the sale of printing equipment to those in the printing business prior to January $I, 1936$, is an instance of such control..$^{35}$ Or, the cartel may seek to control the business in the next economic phase. The Association of Manufacturers of Electrical Equipment entered into an agreement with the Association of Retailers which limited the sale of electrical apparatus to those specializing in this merchandise on the retail level. The agreement affected department stores particularly by eliminating them as purveyors of this type of merchandise. ${ }^{36}$

The R.W.M. used his power to prohibit these agreements only in a few cases. One such prohibition was in the agreement between the Association of Manufacturers of Automobiles and the Association of Suppliers to Automobile Manufacturers. Here the Manufacturers attempted to prevent the Suppliers from selling replacement parts to independent repair men. The Government considered the consequent rise in prices unjustified. ${ }^{37}$ Further control over the use of products is exercised in prohibiting the sale of products to any person not approved by the cartel in a previous stage of the economic process. Also, the cartel may prohibit the export of an article unless exportation is especially permitted. Whether the cartel controls the intermediate stages of production or the producer in the last economic stage makes no material difference..$^{38}$

The power of cartels to influence prices. - The measure prohibiting any increase in prices by cartels has been described above. In November, 1936, the Hitler Government also prohibited any price increase, except as licensed by the price commissioner, in all commodities whether the producers or traders were cartel bound or not. This does not mean that the

35 Decision of the Kammergericht, March I, $193^{6}$ (Ir U 54ro-37).

${ }^{36}$ Electro-abkommen of January 15, 1936, discussed in Kartell Rundschau 135 (1937) (understanding between manufacturers and dealers made to regulate electro-technical market). Another interesting example is found in the requirements for entering the radio wholesale trade. See Ritgen, Berufsanforderungen im Rundfunkgrosshandel und Rechtsprechung des Kartell-und Reichs-Wirtschaftsgericht, Kartell Rundschau 32I (1940).

37 Berthmann, Der Ersatzteilstreit in der Kraftfahrzeugindustrie, Kartell Rundshau 683 (I936).

${ }^{38}$ The problem of a general export quota is discussed under the section of the article dealing with international cartels. 
cartels and groups were precluded from influencing prices. They found a way to retain a good portion of their control.

Long before Hitler and the price-fixing legislation the well organized cartels were aware that rigid price structures were not the best method for protecting the interests of their members. For example, an elaborate system for arriving at prices was worked out by the Association of German Machine Manufacturers. Comparative statements of the costs of all members formed the basis of the system. While it is obvious that calculation schemes which indicate actual costs are difficult to control in the face of varying overheads and differentials in the prices paid for raw materials, still the association developed a good system. It was based on the works of the modern German writers who fostered the so-called "dynamic balance" (Schmalenbach). When the R.W.M. described the scope of activities for the groups and cartels in 1936 , he included the power to formulate these calculation schemes as one of their duties. The principles of this calculation practice are used in compulsory cartels. It was said that "the cartel is entitled to establish a general price basis for services and products. This general price basis may be out- or underbid. If the price basis is established by the calculation scheme, however, it may not be underbid. If a cartel member underbids the general price basis, the acceptor shall report the fact not later than three days after receipt. If the committee of the cartel proves that a member thereof sold under the price based on the calculation scheme the committee may fix miminum prices which will bind the offending member." 39

Another element that gave the cartels power to influence prices can be found in the policy established in the compulsory cartel of the graphic industry into which all the outsiders were forced by decree..$^{\circ 0}$ Here there was a variation of the power to underbid the general price basis. A member could underbid provided he could satisfy the cartel committee that "he is able to fulfill all his obligations to the Reich, state and community, to the organizations of commerce, to the social insurance program, to his employees and to the maintenance of his plant." ${ }_{4 \mathrm{r}}$

These developments multiplied many times and the vast number of cartels led to the formation of a new form of price control-the calculation system. The producers in a stronger technical position enjoyed the advantage of a differential profit, a typical cartel result. Any new technical progress in both equipment and processes increased profits for these stronger enterprises. Cartels whose members are not on an equal research

39 Deutsche Bergwerkszeitung (Jan. 4, 1936).

40 Reichsanzeiger no. 30I (Dec. I3, I937).

${ }^{4}$ Kartell Rundschau 753 (1935): 
level do not provide for the exchange of information, experience, and patents. Therefore the better equipped and stronger members can increase their profit rate continuously; that is the principal significance of the patents to the domestic cartels under the Hitler system. Under the compulsory licensing of patents the weaker members might force the patentee to divulge his secret; however, the profit rate of those engaged in expensive research is still higher because of the payment of royalties. The compulsory license provision merely weakened the bargaining position of the patentee.

This calculation system - the continuous comparison of cost bases of several so-called competitors-gradually became of great importance to the Government. It was thought that comparison between two enterprises in the same industry would be helpful to the development of the national economy. In the artificial wool industry, for instance, the Government specifically requested that new plants be established so that they might be used as a basis of comparison. This desire for comparison should not be mistaken for a new or different species of competition. While the Government supported the calculation scheme on the basis of plant comparison it did not favor competition. The Reichsgericht in one of the last cases it decided on the question of compulsory licenses held that a sufficient reason for the issuance of the license existed when no competition was present in the industry..$^{42}$ The Government obviously did not enjoy the general statements of the Reichsgericht because it promptly deprived this judicial body of its power to grant compulsory licenses.

Disregarding any possible good that might arise out of the comparison and calculation schemes for fixing prices, there is no doubt that the device is used to impress the Government that prices cannot be reduced below an alleged cost basis. Since an accounting system which cannot be tortured to misstate the facts has not yet been devised, the Government keeps a careful watch over such possible subterfuges. As a method of keeping the price levels within reason the price commissioner had all enterprises with annual gross sales in excess of 50,000 RM file their own calculations based on their own average cost. These independent calculations then could be checked against the average submitted by the cartel. The extent

${ }^{42}$ In upholding the license the Patent Office had granted, the court said, "The Patent Office was right in considering it a matter of public interest that competition between the parties would be impossible if a compulsory license was denied. . . . The public interest may be affected without any abuse of the patent monopoly power only because the existence of two different plants and enterprises is always to be considered as a public interest." Decision of the Reichsgericht, December 2I, I935, reported in Mitteilungen der Deutschen Patentanwälte 49 (1936). It is interesting to note that in 1922 the Reichsgericht granted a compulsory license so that additional work might be provided for unemployed workers. 
to which the government will be successful in controlling prices in this manner remains to be seen.

The power of cartels to distribute available production capacity for fulfilling existing needs. - The cartels of the past were more often than not creations of a depressed period. The quota of a cartel member usually was his share of all the existing orders of the industry, and the device was employed to use at least a part of each producer's capacity. In World War I a different use was made of these quota figures. When the needs for war materials were pressing the quotas served to indicate capacity for production, and raw materials for this production were distributed accordingly. The same plan was followed when Hitler began his rearmament program. The existing capacities were utilized for three purposes: a) to produce sufficient war materials; b) to supply the civilian population with sufficient comforts until war actually became a reality; and c) to produce enough goods for exportation so that sufficient foreign exchange could be acquired to pay for the raw materials necessary for the demands of a) and b). ${ }^{43}$

The cartels and groups, therefore, made agreements with each other that attempted to facilitate the proper allocation of available supplies in order best to satisfy the three separate demands. These intercartel agreements led to intercartel quotas. For example, the iron producers had to supply shipbuilders, automobile producers, machine building producers, and the construction industry. Therefore, each of these cartels agreed to take only a certain portion of the output of the iron producers. Since the cartels were originally established to secure to a member a share in the small amount of existing orders, the position of the single member was radically changed. He was now a member of an organization that acted as an agency for the distribution of raw material. In the face of the tremendous amount of business to be done, many members attempted to leave the cartels on the grounds that they had never agreed to any more than certain, not very strict, conditions imposed in consideration for minimum participation in the existing orders. The cartel court held that the shift in the aims of the cartel was not sufficient justification for any member severing his connection. ${ }^{44}$ The voluntary member of the cartel now found himself in an organization he had helped to create but over which he had absolutely no control.

The power of cartels to exercise the legislative function.-A discussion of the rule-making function of the cartels and groups indicates forcefully

43 The United States attempts to meet problems a) and b) by a priority system.

44 Decision of the Kartellgericht of August Io, I937, reported in Kartell Rundschau 209 (1937). The facts of the case dealing with this situation indicate that the plaintiff was particularly embarrassed because large supplies were given to the larger and more influential members of the cartels. 
how members were obliged to obey the managers' commands. These commands also affect persons far beyond the "members" since no one in the nation can obtain what he needs unless he accepts the conditions the cartels or groups impose upon him. There is no real distinction in the position of a customer who must accept goods of a certain standard and quality because of a decision of a cartel or of a legislature. The fact that the legislature has the power to overrule the cartel does not make the rule of the cartel any less a statute than, for instance, the power of Congress to overrule state legislation in those cases involving conflicting jurisdictions eliminates the state legislature as a statute writing body. ${ }^{45}$ Although this phenomenon is interesting from a political science point of view it presents grave practical problems. The legal questions are innumerable; it might be sufficient to mention a few of the more startling ones. Is an agreement between a cartel member and an outsider void if the agreement violates the rules issued by the cartel? Or, is the cartel member merely liable for damages to the cartel? Would the transfer of a used printing press to a printer who started in business after January I, 1936 , in violation of a cartel ruling be classified as a violation of a statute or of a contract? Is a fine imposed on a cartel member by the cartel a contractual or a public fine? The Kammergericht has taken the position that the rules and regulations of a cartel have the force of legislation in those situations where entrepreneurs have been joined to the cartel by governmental decree..$^{6}$ This perhaps indicates that all cartel rules have the force of legislation since the Government is supposed to deal with compulsory cartels in exactly the same way that it deals with others.

A further indication of the legislative force of cartel rules and regulations appears in utterances of the Reichsgericht. While this court held that the cartel rules could not void agreements between members and outsiders their legislative force was recognized. As long as the rules were a reasonable exercise of the cartel's power they were held to be valid. ${ }^{47}$ As far as fines imposed under cartel rules were considered by the Reichsgericht, the rules were given the force of legislation. The seventh senate of the Reichsgericht held that a fine so imposed constituted a public punishment..$^{8}$ This holding can only be correct if the rules under which the fine is imposed are classified as public statutes. ${ }^{49}$

45 The problem is important to the student of German political science and "constitutional" law. This perhaps is a new aspect of Fraenkel's theory of the dual state. See Fraenkel, The Dual State (I937).

${ }^{46}$ Decision of March I, 1938 (Ix U-54ro-37).

47 Decision of the Reichsgericht, reported in R.G.Z. I25-II6.

$1^{8}$ Decision of July 9, 1937, reported in Kartell Rundschau 633 (1937).

49 Metzger, Zeitschrift der Academie für Deutsches Recht 656 (1937). 
There can be no doubt that the full recognition of the legislative power of cartels and groups is almost a complete reality. Take for example the Reichsgruppe Industrie which has suggested that no state legislation is necessary in one of the more important fields of German civil law-reservation of title by the seller. This cartel and group suggest they can take care of all the problems that arise solely by their own rules..$^{50}$

The relationship of the domestic and international cartels. - The most difficult and complicated problem that faced the National Socialist Government was how to obtain the necessary raw materials from abroad both for the civilian supply requirements and more particularly for the stupendous rearmament program. The domestic cartels were of great importance in assisting in acquiring these necessary materials. Their program, however, was not the chief spearhead in the attack on foreign raw materials. Their principal contributions were found in those areas which constitute the domestic aspect of any export trade. First, they continued to divide the losses arising from foreign dumping just as cartels had always done. The Government became a partner cushioning the shock of losses in certain cases. Second, they distributed the export orders that were necessary to secure foreign currency to buy imports among the manufacturers who had excess capacity over and above that required for the rearmament program. Third, they found ways and means to force manufacturers and the public to accept substitutes in place of imports.

The domestic cartels did not come into direct contact with foreign markets. To the extent that the Government did not act directly it based the export and import program on: a) the foreign branches, agencies, or subsidiaries of German enterprises; and b) international cartels based on agreements of German businesses and their foreign counterparts. The concentration of the entire German nation bent as it was on the rearmament program had its effect on every business organization. Those businesses which had any economic foothold in a foreign land were made to serve the Government's program. These "private" agencies, branches, and subsidiaries were given a definite place in the game. They were made to appear as if they were engaged in "business as usual" while technically and politically their aim was preparation for war.

It is interesting to note how these foreign business affiliates of German business were made to serve the National Socialist party. Any independent foreign corporation which had the slightest economic connection with

5० Die Reichsgruppe Industrie und der Eigentumsvorbehalt, Kartell Rundschau 329 (I938). 
a German concern was made subject to German law. Every business transaction the German currency authorities were able to obtain was closely scrutinized so that the rearmament program might be promoted. A decree of the currency authorities provided that "Branches of domestic corporations in foreign countries and legally dependent foreign plants of a resident of Germany, if the place of their management is in Germany [are deemed resident in Germany]. . . . . The same rule applies to a legally independent partnership or corporation whose seat is abroad, provided its management is in Germany..... In regard to the determination of where the place of the management of partnerships and corporations is, the place where the actual decisions relating to the management of the foreign organization are made shall be decisive." ${ }_{5 x}$ This is a simple observation of a part of a most complex and devious arrangement but it indicates the policy of the Government capitalizing on the foreign activities of German business.

The German currency authorities exerted the most pressure on those businesses with foreign subsidiaries or branches which did not find it necessary to invest a great deal of capital in establishing a market. Banks were ordered to cancel long-term credits. Construction companies had to avoid extending financial help to foreign customers, and if a credit transaction was necessary the work had to be refinanced in the foreign country. The chemical and heavier manufacturing industries, however, were encouraged to do business under any conditions; they were subject to less governmental interference.

The managers of those business organizations which did their best to obtain foreign currency received special consideration in certain personal business transactions. In this way they were able to keep funds for themselves in the foreign country. The close control exercised by the National Socialist party over these non-resident party members guaranteed that the funds would be used in a proper manner.

The same "currency law" which forced the foreign assets of German business to serve the war preparation program also forced American subsidiaries in Germany to invest their profits in the German war machine and to pay for goods ordered from German concerns partly in American dollars. For example, if an American parent corporation sought permission to build tankers in Germany, the German Government insisted that a certain percentage of the cost of manufacturing be paid in American dol-

$5 x$ Circular decree of the chief of the German agency for currency administration, October

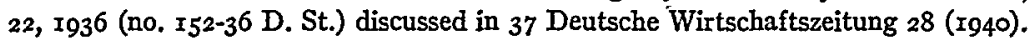


lars. Some day we may learn in how many instances delivery of materials to these American subsidiaries was delayed until the outbreak of the war so that assets of American business might be expropriated for the German war interests.

In addition to furnishing Germany with foreign currency to be used in the purchase of essential raw materials a National Socialist party member in business in a foreign land had other duties. He was constantly on the alert to induce American or other foreign capitalists to open up new sources of supplies for raw materials. Invariably an exclusive arrangement was sought whereby the only one to be supplied was the National Socialist industrial society. Another scheme promoted was the raw material production agreement. The American and foreign raw materials producers were induced to keep production levels so low that prices remained on a high level. This made sense out of an otherwise nonsensical domestic program in Germany where synthetic substitutes were being produced and sold. The general aim was to accomplish these and similar ends without restricting German production in any way. At the same time the operator must attempt to reduce foreign capacity as much as possible.

The policy of early international cartels was discussed in the first article on this subject. It may be repeated, however, that the allegation is often made without justification that the international cartel device is a German device. In the raw material field the device developed not only without active German cooperation but rather in spite of German resistance. ${ }^{52}$ The German was able, however, to turn the practices of the international cartels to his advantage.

The international rubber, tin, and zinc cartels for a long time attempted to solve every difficulty by restricting production. It was not too difficult, therefore, to follow this same policy when properly urged. As it has been said, this low level of production with its accompanying high prices made the German ersatz industry possible. ${ }^{53}$ The rubber and iron situations present an excellent comparison. In I938 Germany decreased the importation of rubber (international cartel controlled) 33.I per cent under the previous year, while imports of iron ore (no international cartel control) were increased 33.4 per cent. ${ }^{54}$ The price level and the restrictive policy of

52 For the German point of view with respect to international raw material cartels see Wagenführ, Kontrollierte N. E. Metalle auf dem Weltmarkt, Kartell Rundschau 593 (1938).

${ }_{33}$ In some cases special agreements between the international cartel and German firms were necessary; in others the international cartel policy alone was sufficient to make the production of the ersatz material profitable.

54 Deutsche Wirtschaftsstruktur in der Wende von 1938 -39, Bericht der Reichskreditgesellschaft IIO (1939). 
the international rubber cartel did not react in any way except to decrease export quotas.55

Because those agricultural countries surrounding Germany found their only outlet for their produce there, Germany enjoyed a further advantage. She could force the substitute products on her helpless neighbors, thereby enhancing the profitableness of her manufacture. This is wilat is known as a "geopolitical" fact. ${ }^{56}$ Thus it is obvious that the German productive capacity was increased as a result of the policies of the international raw material producers. The German army economists were well aware of the potentialities of this phenomenon. The Wehrwirtschaft made it clear that they would encourage only those international cartels which did not restrict German productive capacity in any degree. ${ }^{57} \mathrm{An}$ international cartel had to improve German export conditions to receive the approval of this group. The German industrialist was obliged to keep these limitations in mind when he negotiated with American and foreign producers for the continuance of old or the establishment of new international cartels. Under Hitler, the days in which a patent exchange agreement or a promise to divide world markets was a private affair of the contracting parties were over for at least one of the interested parties.

ss The international rubber cartel decreased the export quotas of the production centers from go per cent of "normal" in 1937 to 45 per cent in July, I938. Kartell Rundschau 212 (1938).

${ }^{56}$ Hearings before the Senate Committee on Patents on S. 2303, 77th Cong., 2nd Sess., pt. 3, at 1340 (I942). (I937).

${ }^{57}$ For an expression of this definite stand see Kartell in Bewegung in Wirschaftsdienst 736 